\title{
Role Allocation in the Media Representation of Participants in Selected Electoral Discourses in Nigeria
}

\author{
By Ayo Osisanwo *
}

\begin{abstract}
Extant literature on media reports in Nigeria have considered different national issues including electoral matters. Few of such studies that considered electoral matters did not emphasize the distribution of roles in the reports. Guided by aspects of Theo van Leeuwen's inventory on the representation of social actors (with emphasis on the account of role allocation), and aspects of the M.A.K. Halliday's systemic functional linguistics (with emphasis on the transitivity system), this study explores the semantic roles allocated to different participants within a sentence. The study examines how social actors, implicated in electoral discourse in Nigeria, are allocated specific roles in the news reports of two widely read news magazines, Tell and The News. Having examined the assignment of roles to social actors associated with the 2003 and 2007 electoral discourses, the findings reveal a systematic ideological bias in giving roles to participants or social actors. While activation is used as a strategy for revealing agency in news reports, passivation is used as a strategy of agency obscuration.
\end{abstract}

Keywords: activation, Nigerian election, passivation, role allocation, social actors

\section{Introduction: News and the Political Situation in Nigeria}

News as an important aspect of human life has been with man from the very origin of life. It has continued to take different forms and shapes from inception till now. In recent times, people have become privileged to have easier access to news more than any other period in the history of human existence. This is probably due to the technological advancement, especially in the domain of communication systems, presence of the Internet and the different social media in the world today. As a result, there has been a great enhancement on the modes through which news is transmitted. Besides, the media often turn their spot-light on the activities of the influential people in society. Such influential people are the people in power, that is, opinion leaders, courts, government, other prominent national figures, celebrities and even the newspaper editors among others (Osisanwo, 2011, p. 1).

The Nigerian political situation, especially the politicians who play the central role in giving the political situation in Nigeria, a shape, have also been often reported by the media. The political situation in Nigeria is such that they get media attention. Politicians fight and struggle for political offices, especially during general elections. To get the attention of the masses, they tend to speak the language the people understand or the language that the voters are willing to receive. However, despite their choices, the reportage of

* Lecturer II, Department of English, University of Ibadan, Nigeria. 
their actions and inactions rests in the hands of the media. Hence, one occasionally gets to hear some comments from some politicians expression, including - the media did not represent my speech properly, that was not what I meant, and so forth. Therefore, beyond the language used by the politicians, the representations given to them by the media seem to sink deeper in the minds of the electorate than the actual utterances. With the media's use of language, they play a vital role in shaping issues in society and setting the boundaries of what is talked about and how it is talked about (Henry and Tator, 2002; Taiwo, 2008). As a veritable tool in the propagation of any idea, the print media serve to inform the public. Despite all of these, what generally goes (almost) unnoticed, however, is the ideological load as well as meaningmaking function of news, especially in the way in which it is reported. People and readers generally are oblivious to the fact that news is a social, cultural, and ideological construction. It is not a natural phenomenon that emerges from facts in real life. Rather, it is that which is socially and culturally determined. News producers are social agents in a network of social relations who reveal their own stance towards what is reported. In the light of this, the present study adopts Theo van Leeuwen's framework on the representation of social actors, a powerful tool of enquiry within CDA, to the analysis of the data gleaned from two Nigerian newsmagazines, Tell and The News on the Nigerian electoral discourses. This is supported with aspects of Halliday's systemic functional linguistics. With emphasis on the allocation of roles to social actors by Tell and The News magazines on the Nigerian electoral discourses, Nigeria General Elections (NGE), this study examines the representational strategies with a focus on the headlines and cover stories. Since the news consumers are the readers or people, who are passive receivers of news from media controllers, this study examines how the media impress their ideological affiliations on the minds, feelings, opinions and attitudes of the people.

\section{Related Studies and Statement of the Problem}

In a bid to uncover the workings of language, especially in the media field, Fairclough (1989, 1992) van Dijk (1998), Scollon (1998) Pan (2002), Massi (2008), Taiwo (2004, 2008), Nunn (2008), Odebunmi (2008), Alo (2008), Chiluwa (2005, 2008), Osisanwo (2011, 2012, 2013), Oyeleye and Osisanwo (2013a and 2013b), among others, have carried out different studies on media discourse. Among them, only Taiwo (2004, 2008), Odebunmi (2008), Alo (2008), Chiluwa $(2005,2008)$, Osisanwo $(2011,2012)$, Oyeleye and Osisanwo (2013a and 2013b) delved into Nigeria-related news discourse. Not with standing their concentration on the Nigerian-based media issues, they focused on other different national issues. Studies that bother on electoral matters, that is Osisanwo (2012, 2013), Oyeleye and Osisanwo (2013a, 2013b) examine other aspects of Nigerian electoral matters without paying attention to the allocation of roles to social actors in news reports.

Osisanwo (2012) carried out a study, similar to Nigerian electoral discourse. The study investigates the ways the cover stories in two Nigerian 
news magazines, Tell and The News, conversationalise the ideological pursuits of social actors in the 2003 and 2007 general elections in Nigeria. Adopting the Fairclough's model on discourse as theoretical framework, the study discovers that the discourse patterns that expressed ideological pursuits in the reports were generally non-neutral. The analysis shows that both magazines adopted the radical and pragmatic approaches to pattern the quotation sequence as Quoted-Process-Sayer to shape, discursively, the readers' perceptions.

Oyeleye and Osisanwo (2013a) carry out a study on the lexicalization in media representation of the 2003 and 2007 general elections in Nigeria. This study investigates the ways the cover stories in two Nigerian news magazines, lexically, express the ideological pursuits of social actors in the 2003 and 2007 general elections in Nigeria. This paper adopts Fairclough's theoretical model on "wording" which is equivalent to Halliday's theoretical model on "lexicalisation", and discovers that both magazines used linguistic tools to represent their ideological affiliations, that is, election in Nigeria is a dirty game and politicians are insincere. Lexicalisation and intertextuality intermingled to depict contextual lexical choices. In a related study, Oyeleye and Osisanwo (2013b) carry out a study on the expression of ideologies by the media on electoral matters. The study investigates the ways that cover stories in selected Nigerian news magazines express the ideological pursuits of social actors. The study claims that ideologies are expressed, acquired, confirmed, changed and perpetuated through discourse. They are generally reproduced in the social practices of their members. It claims that the media put to use the ideological polarization between the ideological structures of ingroups and outgroups, such that ingroups typically emphasise their own good deeds while they de-emphasise their bad deeds; on the other hand, outgroups de-emphasise or even totally deny their own bad deeds, while they emphasise their good deeds. Meanwhile, the bane of Osisanwo (2013) is on the representation of discourse on the third-term plot by Chief Olusegun Obasanjo.

The present study deviates from the concern of both Osisanwo and Oyeleye (2013a) and (2013b) and Osisanwo (2013). It is neither concerned with lexicalisation nor expressions of ideology in the media representations of the Nigerian electoral discourse. It is not also entirely focused on the representation of discourse on the third-term plot. The present study is basically concerned with how The News magazines allocate roles to the represented social actors in their reports.

\section{Theoretical Framework: Van Leeuwen's Role Allocation Category and Halliday's Transitivity System}

The allocation of roles to participants in a discourse is a function of what is carried out by the participants. It is where social actors are represented through the roles they play. According to van Leeuwen, this bothers on who is represented as agent (actor), who is patient (goal) with respect to a given action? (1996, p. 3). This is considered important, as "there need not be congruence between the roles that social actors actually play in social practices 
and the grammatical roles they are given in texts" (van Leeuwen, 1996, p. 43). Social actors can be given active roles or passive roles to play. When they are given the active role to play, that is, represented as dynamic forces in a given activity, activation occurs; when they are given passive roles to play, that is, described as undergoing a given activity, passivation occurs. Passivation, as noted by Leeuwen, can be further broken into subjected (social actors that are treated as objects) beneficialised (the third party in a discourse which benefits from it). Van Leeuwen's inventory can be broadly located in the aspects of the Hallidayan systemic functional linguistics which are called the transitivity system. Van Leeuwen's role allocation has to do with semantic roles allocated to different participants within a sentence.

In the transitivity system, Halliday sees the ideational function of the clause as meaning "representation" (1985, p. 101), that is, it is realised at the level of the clause as representation. The clause functions to represent our experience of the world as language users. This is because "a fundamental property of language is that it enables human beings to build a mental picture of reality, to make sense of their experience of what goes on around them and inside them" (Halliday, 1994, p. 106). This system allows the clause to be broken down into three general components: the process, the participant and the circumstance (Halliday, 1985; 1994; Bloor \& Bloor, 1995; Butt, Fahey, Spinks, and Yallop, 1995; Simpson, 1993; Thompson, 1996; Martin, 2001; Teo, 2000). The "concepts of process, participant and circumstance are semantic categories which explain in the most general way how phenomena of the real world are represented as linguistic structures" (Halliday, 1985, p. 102). It is obvious that, as language users, in representing our experience of the world, we select from a number of different processes, participants and circumstances in order to get a particular message across. In like manner, text producers (such as media reporters) select from a number of processes and participants to feed their consumers. Only one process is available in a clause, and this "can be classified according to whether it represents actions, speech, states of mind or simply states of being" (Simpson, 1993, p. 88).

Processes are typically realised by verbal groups. Halliday identifies three main process types: material, mental and relational. He also identifies three additional process types: behavioural, existential and verbal. These other three are said to be located at the borderlines of the first three. Halliday distinguishes between inner and outer experience: "between what we experience as going on "out there", in the world around us, and what we experience as going on inside ourselves, in the world of consciousness" (Halliday, 2004, p. 170). The material and mental process clauses represent the outer and inner experience respectively. The relational process clauses include those of identifying and classifying, when one fragment of experience relates to another. In the group of the other three, Halliday locates behavioural processes on the borderline between material and mental processes, and states that they "represent the outer manifestations of inner workings, the acting out of processes of consciousness ... and physiological states" (Halliday, 2004, p. 171). The verbal processes, which involve saying and meaning enacted in language, are situated between 
mental and relational processes. Finally, the existential process clauses are on the borderline of relational and material. They are concerned with existence or happening. "Clauses of different process types thus make distinctive contributions to the construal of experience in text" (Halliday, 2004, p. 174). The six types of processes and the types of actions or events which they represent are illustrated below with examples adapted from Halliday (2004).

- Material: During the European scramble for Africa, Nigeria fell to the British.

- Behavioural: People are laughing.

- Mental: The Ibos did not approve of kings.

- Verbal: Can you tell us about the political and cultural make-up of Nigeria?

- Relational: Every fourth African is a Nigerian.

- Existential: Today there's Christianity in the south.

Figure 1a is adapted from Halliday (1994, p. 108). Halliday describes the "concrete visual metaphor" or "model of experience, as interpreted through the grammatical system of transitivity", as "one of regions within a continuous space; but the continuity is not between two poles, it is round in a loop" (1994, p. 107). The process types determine how the system of transitivity functions ideationally to convey at the level of clause as representing experiences of one's physical world, and the world of relations and consciousness.

\section{Figure 1a. Process Types}

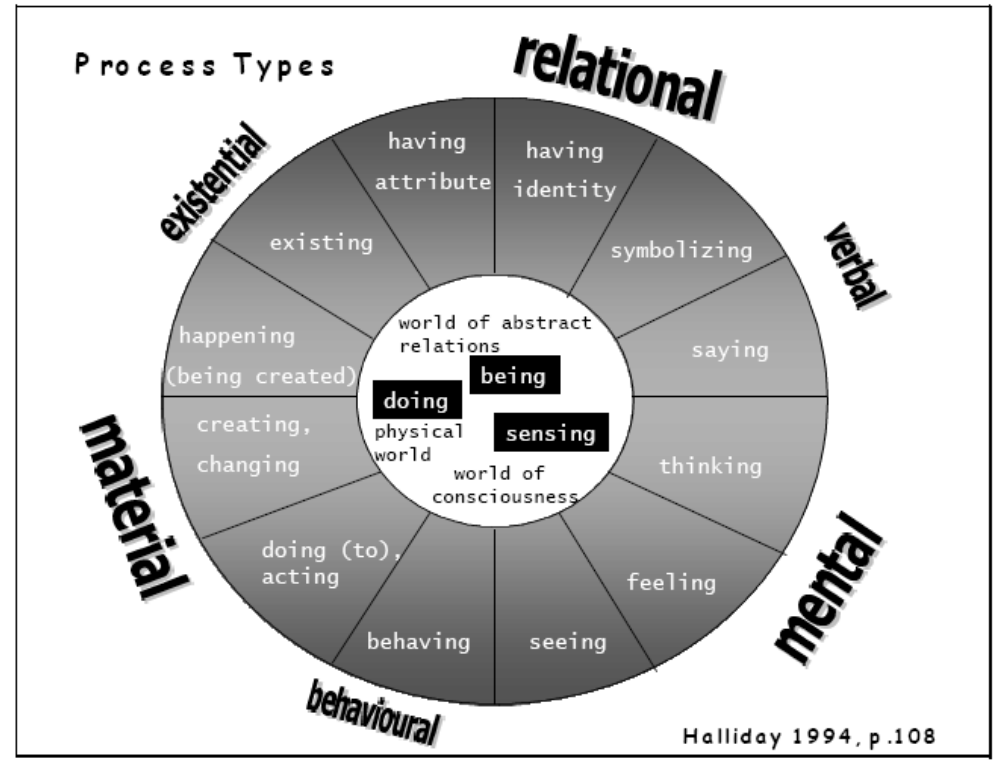

Source: Halliday, 1994, p. 108.

Since some verbs are capable of bringing about confusion, Butt et al. (1995, p. 47) warn that "rather than thinking of particular verbs as always giving expression to one process type, we should think about how a particular verb is functioning in its context". In showing the possible usages of the same 
verb in different contexts, Butt et al. (1995, p. 47) offer the following examples of the English verb feel which can function "as a material, a projecting or a relational process depending on its relationship with the other elements in the clause":

- I felt the wood and decided it needed more sanding - material process (doing).

- I felt that I was at a crossroads in my life - projecting process (thinking).

- I felt tired - relational process (a kind of being).

They are as follows:

Material processes involve processes of doing. They usually involve concrete or tangible actions (Eggins, 2004, p. 215). Material processes involve action or the doing of something, that is, happenings or events that people do. According to Thompson (1996, p. 79), this process usually signals physical actions, like "running, throwing, scratching, cooking, sitting down, and so on". The participant(s) associated with material process are the actor (or agent) and in some cases the goal (Halliday, 1985/1994). While the actor is a functional label for the active participant in a specific process type, the goal is the person or the entity that is affected by the performance of the material process of the actor. In some cases, this actor is not simply doing something to or for himself/herself; rather, the actor is extending the action towards someone or something else. This other participant is referred to as the goal. The actor and the goal are direct participants. We also have the participant called range. They are less independent participants, which in traditional grammar are referred to as cognate objects. The goal is sometimes also referred to as the beneficiary. If it is the participant to whom something is given, it is called recipient; if it is the one to whom something is done, it is referred to as client (Martin, Matthiessen, \& Painter, 1997; Eggins, 2004).

\section{Presentation of Data and Analysis}

The allocation of roles in the representation of social actors is a very important and useful tool in getting the ideology of news or text producers. In our data, while some of the social actors are represented as "agent" (actor), some are represented as "patient" (goal) in relation to a given action, and depending on the intention of the news producers. Activation is adopted by both magazines to identify the roles of specific actions and actors on the political landscape in Nigeria. Social actors are sometimes clearly distinguished in specific reports with the grammatical strategy of agency highlighting through activation. When text producers activate social actors, they are presented as the very active forces behind specific events, whereas when passivated, they are represented as recipient of the activity/event. Table 1 and Figure $1 \mathrm{~b}$ show how participants are represented in the media.

To carry out our analysis, we deploy aspects of both van Leeuwen and M.A.K. Halliday's role allocation theories in order to determine how both Tell 
and The News magazines have allocated roles to the social actors. From the 520 editions of both magazines (published from January, 2003 to December, 2007), 81 cover stories relating to Nigeria General Elections (NGE) in Tell (50) and The News (31), covering 2003 and 2007 elections, were purposively selected. The cover stories were subjected to content analysis.

\section{Participants in the Representation of NGE}

Table 1 and Figure $1 \mathrm{~b}$ provide an illustration of the use of transitivity participants with an emphasis on material process in Tell and The News in reporting the NGE. Table 1 shows that The News used a wider range of participants in material clauses than Tell. In Tell, "Actor" occured in 50\% of the material clauses, while "Goal" takes $38.8 \%$ of the material clauses. On the other hand, in the case of The News, "Actor" occured in $52.7 \%$ of the material clauses, while "Goal" takes $47.3 \%$ of the material clauses. This shows the extensive use of or creation of the "Actor" role in their reports. Also, "Recipient" and "Range" occured $7.5 \%$ and $3.7 \%$, respectively in Tell, while there is no occurrence of such at all in The News. In other words, while the participants "Actor", "Goal", "Recipient" and "Range" were used in reporting NGE stories in Tell, only "Actor" and "Goal" were used in The News. This shows a striking difference in their mode of reporting issues.

Table 1. Summary of Material Process Participants in the Representation of NGE

\begin{tabular}{|l|c|c|c|c|}
\hline & \multicolumn{2}{|c|}{ Tell } & \multicolumn{2}{c|}{ The News } \\
\hline & Frequency & Percentage & Frequency & Percentage \\
\hline Actor & 80 & $50 \%$ & 118 & $52.7 \%$ \\
\hline Goal & 62 & $38.8 \%$ & 106 & $47.3 \%$ \\
\hline Recipient & 12 & $7.5 \%$ & 0 & $0 \%$ \\
\hline Client & 00 & $0 \%$ & 0 & $0 \%$ \\
\hline Range & 06 & $3.7 \%$ & 0 & $0 \%$ \\
\hline Attribute & 00 & $0 \%$ & 0 & $0 \%$ \\
\hline & $\mathbf{1 6 0}$ & $\mathbf{1 0 0 \%}$ & $\mathbf{2 2 4}$ & $\mathbf{1 0 0 \%}$ \\
\hline
\end{tabular}

Figure 1b. Representation of Material Process Participants in the Representation of NGE

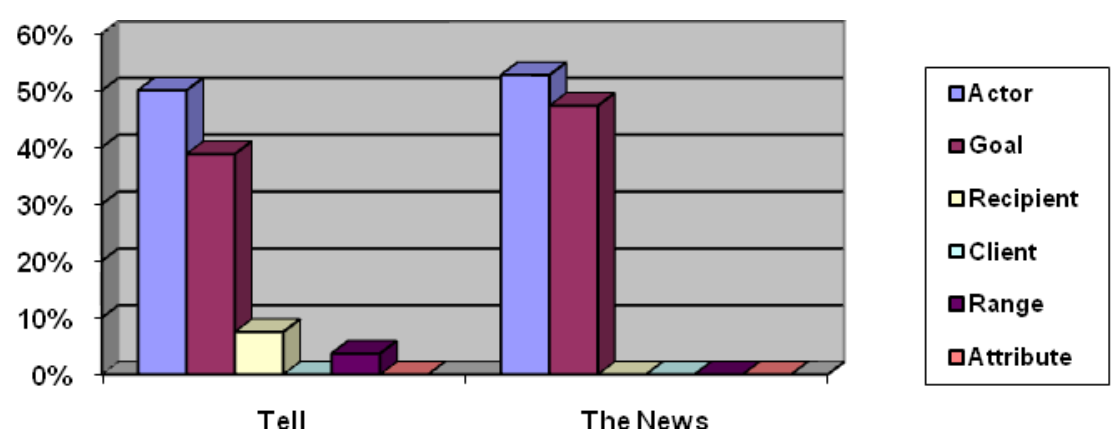


The samples below show that both Tell and The News use material processes as a strategy in telling their stories. The actor role is mostly occupied by a proper noun.

\begin{tabular}{|l|l|l|}
\hline PDP, OBJ & woo & opposition \\
\hline Actor & Process: Material & Goal \\
\hline S & F/P & C \\
\hline
\end{tabular}

Source: The News magazine (May 12, 2003).

\begin{tabular}{|l|l|l|}
\hline OBJ & wants & six more years \\
\hline Actor & Process: Material & Goal \\
\hline S & F/P & C \\
\hline
\end{tabular}

Source: The News magazine (May 9, 2005).

\begin{tabular}{|l|l|l|}
\hline OBJ & hatches & fresh plot \\
\hline Actor & Process: Material & Goal \\
\hline S & F/P & C \\
\hline
\end{tabular}

Source: The News magazine (July 25, 2005).

\begin{tabular}{|l|l|l|l|}
\hline & Reps & offered & N25 Billion \\
\hline Actor & Recipient & Process: Material & Goal \\
\hline & S & F/P & C \\
\hline
\end{tabular}

Source: The News magazine (November 28, 2005).

\begin{tabular}{|l|l|l|}
\hline Obasanjo's cabinet & split & over third-term \\
\hline Goal & Material & Actor \\
\hline S & F/P & A \\
\hline
\end{tabular}

Source: Tell magazine (May 8, 2006).

The extracts below further explain the use of material process and participants with emphasis on the clause types used by the different magazines in reporting their views.

- Extract 1: PDP, OBJ woo opposition (The News, May 12, 2003).

Extract 1 is an example of a material process clause with both human and non-human actors in the subjected position. The clause is realised as a transitive clause. The action presented is direct. The subject, "PDP, OBJ" is used by the text producer to represent the actor(s) who performed the act of wooing on the opposition. The clause helps in bringing out the role played by the President $(\mathrm{OBJ})$ and his political party in wooing their political opponents to their side, especially in order to take further dominance.

- Extract 2: The President lied (Tell, May 26, 2006 ).

The alpha $(\alpha)$ clause "The President lied" is a material process with a human actor in the subjected position. The action is a direct action performed by an identified actor. The President is described as a liar. When the 
insinuations on argument for third-term agenda finally crashed, the media and the masses thought that the President would come to the open to confess his involvement, condemn the act, and ask for forgiveness from Nigerians. On the contrary, the President only denied any involvement in the third term plot. The ideological affiliation of Tell is shown in this particular report which is relayed in the SP structure that the President intentionally lied. Hence, he is a liar. The structure used is: Material Process - action process - intention process.

- Extract 3: Campaign violence spreads (The News, March 26, 2007).

The News magazine used the material process strategy in extract 3 . However, it is an event process which omits human actors. The action is carried out by a non-human actor. It is represented by the mh-type of a nominal group which exemplifies agency obscuration, by using campaign violence and not mentioning the human actors involved in the spreading of violence. Ideologically, the text producer tries to generalise the actors involved in the spreading of campaign violence. The agentless clause leaves the mind of the readers open to think of politicians in general as being involved in the act, or filling in the gap, depending on their world view.

- Extract 4: Obasanjo endangers democracy (Tell, January 26, 2004).

In extract 4, Chief Obasanjo is portrayed as an enemy of progress or peaceful democratic governance. He is portrayed as an active participant in the destruction of democracy in Nigeria. This goes a long way in convincing the masses and electorate not to believe in his person. While the ideology behind this construction calls Chief Obasanjo to question, it calls the electorate to action, so that the government of the people (will remain theirs), by the people (will not be by another people) and for the people (will not be for some other people). The realisation of activation by participation (grammatical participant roles) foregrounds the action of the president. The activation of the promoter of democratic danger casts aspersion on the integrity of the agent of danger, Obasanjo.

- Extract 5: Political cold war between the President and his Vice worsens (Tell, February 15, 2005).

The pre-modification of the process noun with the word "political" is used in the sample above to activate the type of war that ensues between the President and his Vice. This establishes the angle from where to view the disagreement between the two leaders.

- Extract 6: Battle of the general (Tell, January 20, 2003).

In extract 6 , the activation of social actors is exemplified by the text producer by the post-modifying of the generals the process noun battle. The 
construction activates the actors that are involved in the purported battle. The two Generals, General Obasanjo and General Buhari are portrayed as leaders who battle for their selfish interest and not for the comfort or the interest of the masses. The text producers portray the two Generals as dictators during their military regimes. The battle of who takes over the seat at Aso Rock between ANPP's General Buhari and PDP's General Obasanjo becomes a course for concern.

- Extract 7: Plotters and campaigners for two or six more years for President Olusegn Obasanjo are back at work again, despite sharp rebuttals by President Obasanjo and his aides that no such open agenda exists (The News, July 25, 2005).

- Extract 8: In spite of denials by President Olusegun Obasanjo, speculations about his self succession plot refuse to die (The News, August 29, 2005).

Extracts 7 and 8 show cases of the use of circumstantialisation for the purpose of activation. The construction activates President Obasanjo and his aides as the social actors who deny the existence of any third term agenda. Text producers use circumstantialisation to background actors and foreground issues and processes.

\section{Relational Participants in the Representation of NGE Reports}

Table 2 shows a striking difference between the transitivity participants in relational process clauses in the two magazines. While Tell had 188 clauses, The News had 116 clauses. However, there are some areas of convergence in the two magazines. For instance, the occurrence of the carrier/attribute, token/value and possessor/possessed in Tell were 34\%, $8.5 \%$ and $7.5 \%$, respectively, while those in The News were $32.8 \%, 10.3 \%$ and $6.9 \%$, respectively. This also shows the preponderance of carrier/attribute participant roles in the creation of relational clauses in the two magazines.

Table 2. Summary of Relational Process Participants in the Representation of NGE

\begin{tabular}{|l|c|c|c|c|}
\hline & \multicolumn{2}{|c|}{ Tell } & \multicolumn{2}{c|}{ The News } \\
\hline & Frequency & Percentage & Frequency & Percentage \\
\hline Carrier & 64 & $34 \%$ & 38 & $32.8 \%$ \\
\hline Attribute & 64 & $34 \%$ & 38 & $32.8 \%$ \\
\hline Token & 16 & $8.5 \%$ & 12 & $10.3 \%$ \\
\hline Value & 16 & $8.5 \%$ & 12 & $10.3 \%$ \\
\hline Possessor & 14 & $7.5 \%$ & 08 & $6.9 \%$ \\
\hline Possessed & 14 & $7.5 \%$ & 08 & $6.9 \%$ \\
\hline & $\mathbf{1 8 8}$ & $\mathbf{1 0 0 \%}$ & $\mathbf{1 1 6}$ & $\mathbf{1 0 0 \%}$ \\
\hline
\end{tabular}


Figure 2. Representation of Relational Process Participants in the Representation of NGE

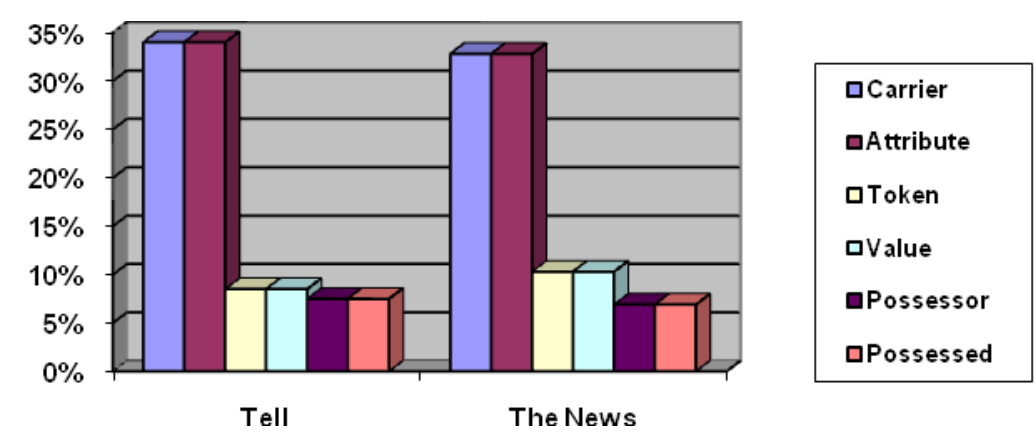

Let us consider the following extracts:

\begin{tabular}{|l|l|l|}
\hline IBB's campaign & is & in disarray \\
\hline Carrier & Relational: intensive & Attribute \\
\hline S & F/P & A \\
\hline
\end{tabular}

Source: Tell magazine (August 2, 2004).

\begin{tabular}{|l|l|l|}
\hline These & are & the odds against the Khalifa \\
\hline Identified/token & Relational & Identifier/value \\
\hline S & F/P & C \\
\hline
\end{tabular}

Source: Tell magazine (February 14, 2005).

\begin{tabular}{|l|l|l|}
\hline Third-term fall out - OBJ & is & on revenge mission \\
\hline Carrier & Process: Relational & Attribute \\
\hline S & F/P & A \\
\hline
\end{tabular}

Source: The News (July 10, 2006).

\begin{tabular}{|l|l|l|}
\hline Vengeance & is & his President Olusegun Obasanjo \\
\hline Possession & Process: Relational & Possessor \\
\hline S & F/P & C \\
\hline
\end{tabular}

Source: The News (July 10, 2006).

\begin{tabular}{|l|l|l|}
\hline This & is & the way forward, an agenda to rescue Nigeria \\
\hline Token & Process: Relational & Value \\
\hline S & F/P & C \\
\hline
\end{tabular}

Source: The News (May 29, 2006).

The examples below further explain the use of relational process with emphasis on the clause types used by the different magazines in reporting their views.

- Extract 9: The way forward, an agenda to rescue Nigeria (The News, May 29, 2006).

Extract 9 above signifies the existence of row and rancour in Nigeria. It signifies the need to deliver the country from the imminent doom occasioned 
by corrupt leaders and political connivers who are bent on destroying the country for selfish interests. If the extract is recast from its state, the full realisation can take a different form like "This is the way forward, an agenda to rescue Nigeria". This identifies better with the relational process. The value of the identified relational token is given by an unidentified individual.

- Extract 10: Third-term fall out - OBJ on revenge mission (The News July 10, 2006).

Extract 10 signifies the relationship between two entities, that is, the carrier of a particular attribute and the attribute. The revenge mission of Chief Obasanjo signifies the existence of his self-succession bid despite his continuous denial of such intentions. His mission (attribute) also calls to order the other politicians who could not play the role of handing him the required third-term ticket. The phrase can therefore be realised in its clausal form as "Third-term fall out - OBJ [is] on revenge mission".

\section{Verbal Participants in the Representation of NGE Reports}

Table 3 and Figure 3 provide an illustration of the use of transitivity participants, with emphasis on verbal process, in Tell and The News in reporting the NGE. The table shows that "Sayer" and "Verbiage" in Tell and The News had $42.9 \%$ and $41.7 \%$ instances of occurrence, respectively. However, while Tell had 14.2\% instances of "Receiver", The News had 16.6\%.

Table 3. Summary of Verbal Process Participants in the Representation of NGE

\begin{tabular}{|l|c|c|c|c|}
\hline & \multicolumn{2}{|c|}{ Tell } & \multicolumn{2}{c|}{ The News } \\
\hline & Frequency & Percentage & Frequency & Percentage \\
\hline Sayer & 06 & $42.9 \%$ & 10 & $41.7 \%$ \\
\hline Verbiage & 06 & $42.9 \%$ & 10 & $41.7 \%$ \\
\hline Receiver & 02 & $14.2 \%$ & 04 & $16.6 \%$ \\
\hline & $\mathbf{1 4}$ & $\mathbf{1 0 0 \%}$ & $\mathbf{2 4}$ & $\mathbf{1 0 0 \%}$ \\
\hline
\end{tabular}

Figure 3. Representation of Verbal Process Participants in the Representation of NGE

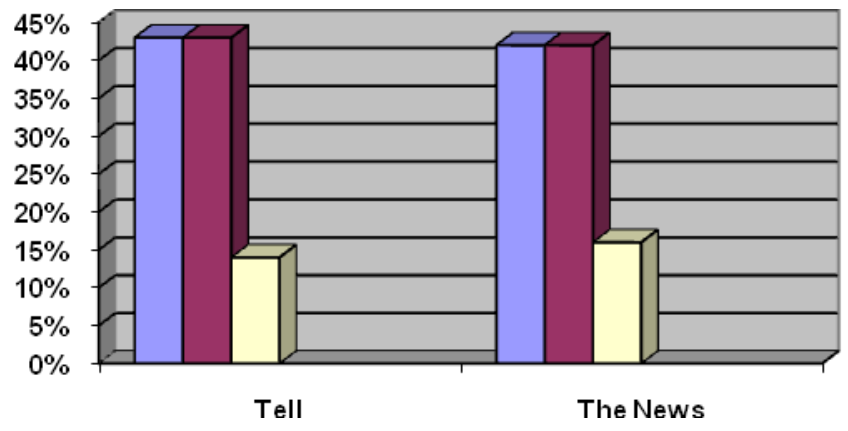

$$
\begin{aligned}
& \text { 口Sayer } \\
& \text { averbiage } \\
& \text { QReceiver }
\end{aligned}
$$


Let us consider the following extracts and their analyses:

\begin{tabular}{|l|l|l|}
\hline ANPP's presidential candidate & confirms & Nigerians worst fears \\
\hline Sayer & Verbal & Verbiage \\
\hline S & F/P & C \\
\hline
\end{tabular}

Source: Tell magazine (January 27, 2003).

\begin{tabular}{|l|l|l|}
\hline $\begin{array}{l}\text { The Independent Natioanl } \\
\text { Electoral Commission (INEC) }\end{array}$ & says & $\begin{array}{l}\text { it is ready to do the seemingly } \\
\text { impossible }\end{array}$ \\
\hline Sayer & Verbal & Verbiage \\
\hline S & F/P & C \\
\hline
\end{tabular}

Source: Tell magazine (February 23, 2003).

\begin{tabular}{|l|l|l|}
\hline Guobadia & threatens & to resign \\
\hline Sayer & Process: Verbal & Verbiage \\
\hline S & F/P & \\
\hline
\end{tabular}

Source: The News magazine (June 12, 2006).

\begin{tabular}{|l|l|l|}
\hline $\begin{array}{l}\text { Ex-military ruler, General } \\
\text { Ibrahim Badamosi Babangida }\end{array}$ & proclaims & $\begin{array}{l}\text { his interest in the 2007 } \\
\text { Presidential race }\end{array}$ \\
\hline Sayer & Process: Verbal & Verbiage \\
\hline S & F/P & C \\
\hline
\end{tabular}

Source: The News magazine (April 10, 2006).

\begin{tabular}{|l|l|l|}
\hline "I am under pressure" & says & Iwu, INEC boss \\
\hline Verbiage & Process: Verbal & Sayer \\
\hline S & F/P & C \\
\hline
\end{tabular}

Source: The News magazine (June 12, 2006).

The examples below further explain the use of verbal process with emphasis on the clause types used by the different magazines in reporting their views.

- Extract 11: INEC says it is ready to do the seemingly impossible (Tell April 2, 2007).

In shaping their ideological viewpoints on electoral issues, both magazines use verbalisation processes. This involves giving voice to newsworthy individuals. They construct their reports and stories around their comments. In the clause, INEC says it is ready to do the seemingly impossible, INEC is the non-human actor whose voice is reported. INEC (represented by the Chairman) is the sayer of the verbiage, that is, "the seemingly impossible". This statement supports the ideology that INEC is not dependable and not independent. The INEC boss couches his verbiage around credibility and reliability. The target is the electorate. The commission is painted as a body whose credibility is lost and only tries to mend its broken pot before the electorate.

- Extract 12: YAGG says "Enough is enough for Obasanjo", "Go back to Otta Farm" (Tell, May 1, 2006). 
The sentence above is reported to support the stance of the text producer. The news medium is ideologically opposed to the purported self-succession bid of Chief Obasanjo. Therefore, the non-human sayer, YAGG, whose view identified with that of the text producer, is quoted as representative of the electorate's demand that Chief Obasanjo should not amend the constitution because of his purported desire to stay in office beyond 2007.

\section{Mental Participants in the Representation of NGE Reports}

Table 4 and Figure 4 provide an illustration of the use of transitivity participants with emphasis on mental process, in Tell and The News in reporting the NGE. The table shows that there are equal percentages, that is $50 \%$ each, of "Senser" and "Phenomenon" participants in both Tell and The News. However, whereas Tell had four instances of "Senser" and "Phenomenon" The News had just one of each. This shows that Tell uses the mental participants more than The News, although this is not too obvious.

Table 4. Summary of Mental Process Participants in the Representation of NGE

\begin{tabular}{|l|c|c|c|c|}
\hline & \multicolumn{2}{|c|}{ Tell } & \multicolumn{2}{c|}{ The News } \\
\hline & Frequency & Percentage & Frequency & Percentage \\
\hline Senser & 04 & $50 \%$ & 01 & $50 \%$ \\
\hline Phenomenon & 04 & $50 \%$ & 01 & $50 \%$ \\
\hline & $\mathbf{0 8}$ & $\mathbf{1 0 0 \%}$ & $\mathbf{0 2}$ & $\mathbf{1 0 0 \%}$ \\
\hline
\end{tabular}

Figure 4. Representation of Verbal Process Participants in the Representation of NGE

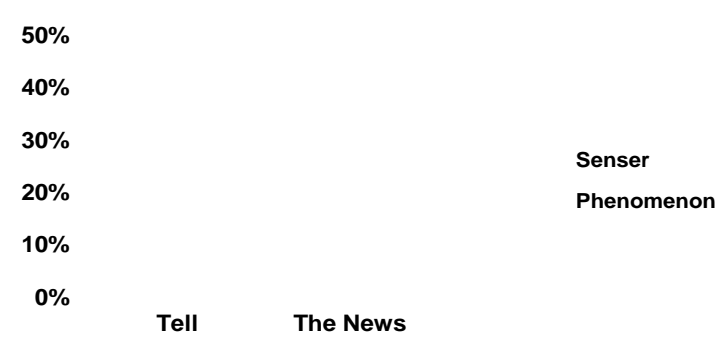

Let us consider the following extracts:

\begin{tabular}{|l|l|l|}
\hline Nigerians & fear & for 2003 \\
\hline Senser & Process: Mental & Phenomenon \\
\hline S & F/P & A \\
\hline
\end{tabular}

Source: Tell magazine (January 6, 2003). 


\begin{tabular}{|l|l|l|}
\hline $\begin{array}{l}\text { A selfish General/desperate } \\
\text { President }\end{array}$ & troubled & $\begin{array}{l}\text { about what would happen } \\
\text { to him }\end{array}$ \\
\hline Senser & Process: Mental & Phenomenon \\
\hline S & F/P & A \\
\hline
\end{tabular}

Source: The News magazine (February 26, 2007).

The examples below further explain the use of the mental process with emphasis on the clause types used by the different magazines in reporting their views.

- Extract 13: Nigerians fear for 2003 (Tell, January 6, 2003).

In shaping their ideological pursuits on the NGE, both magazines use mental processes to encode meanings of thinking and feeling. This process speaks to the psychological consciousness of the electorate. Actions are psychologically, rather than physically, expressed. In the clause, the electorate, that is Nigerians, are the senser, while the 2003 election is the phenomenon. Tell tries to generalise the number of people who are jittery about the 2003 elections in Nigeria. Nigerians are involved in the conscious processing of the thought process.

- Extract 14: Selfish General/desperate President troubled about what would happen to him (The News, February 26, 2007).

In extract 14, the text producer discloses the psychological situation of the General (the senser) who becomes troubled because of the phenomenon, what would happen to him. This confirms The News' ideology that Nigerian politicians are insincere and selfish. It also points to their avaricious desperation to either get to power or remain in power. The verb troubled is used to position the mental state of the sensor.

\section{Existential Participants in the Representation of NGE Reports}

Table 5 and Figure 5 provide an illustration of the use of transitivity participants, with emphasis on the existential process in Tell and The News in reporting the NGE. The table shows that there is an equal percentage, that is $100 \%$, each of "Existent". This is because there is no other participant in the existential process. However, whereas Tell had 10 instances of the existent participant, The News had 14. This indicates that The News uses behavioural participants more than Tell.

Table 5. Summary of Existential Process Participants in the Representation of NGE

\begin{tabular}{|l|c|c|c|c|}
\hline & \multicolumn{2}{|c|}{ Tell } & \multicolumn{2}{c|}{ The News } \\
\hline & Frequency & Percentage & Frequency & Percentage \\
\hline Existent & 10 & $100 \%$ & 14 & $100 \%$ \\
\hline & $\mathbf{1 0}$ & $\mathbf{1 0 0 \%}$ & $\mathbf{1 4}$ & $\mathbf{1 0 0 \%}$ \\
\hline
\end{tabular}


Figure 5. Representation of Existential Process Participants in the Representation of NGE

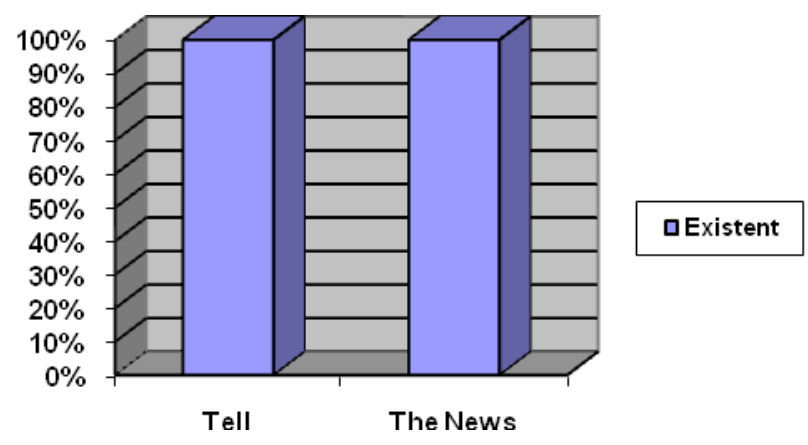

Let us consider the following extracts:

\begin{tabular}{|l|l|l|}
\hline There & are & threats to civil rebellion \\
\hline $\mathbf{S}$ & Process: Existential & Existent \\
\hline
\end{tabular}

Source: The News magazine (May 5, 2003).

\begin{tabular}{|l|l|l|}
\hline Here & is & the retired generals' agenda for 2007 \\
\hline & Existential & Existent \\
\hline S & F/P & C \\
\hline
\end{tabular}

Source: Tell magazine (March 1, 2004).

\begin{tabular}{|l|l|l|}
\hline There & is & no way for IBB \\
\hline & Process: Existential & Existent \\
\hline S & F/P & C \\
\hline
\end{tabular}

Source: The News magazine (November 27, 2006).

The examples below further explain the use of existential process with emphasis on the clause types used by the different magazines in reporting their views.

- Extract 15: Here is the retired general's agenda for 2007 (Tell, March 1, 2004).

Both magazines use existential process to indicate the existence of a particular issue. Unlike other processes, this is not used to indicate who does what, it only indicates the existential value. For instance, the extract above only informs the text consumers that the controversy on whether or not the General would contest the forthcoming election or not should not be the issue. His agenda is overt. This presents the General's agenda at the polls as existent after all.

\section{Behavioural Participants in the Representation of NGE Reports}

Table 6 and Figure 6 provide an illustration of the use of transitivity participants, particularly the behavioural process, in Tell and The News in 
reporting the NGE. The table shows that there is an equal percentage, that is $50 \%$ each, of "Behaver" and "Behaviour" participants in both Tell and The News. However, whereas Tell had 8 instances of both, The News had just 2. This shows that Tell used the behavioural participants more than The News.

Table 6. Summary of Behavioural Process Participants in the Representation of NGE

\begin{tabular}{|l|c|c|c|c|}
\hline & \multicolumn{2}{|c|}{ Tell } & \multicolumn{2}{c|}{ The News } \\
\hline & Frequency & Percentage & Frequency & Percentage \\
\hline Behaver & 08 & $50 \%$ & 02 & $50 \%$ \\
\hline Behaviour & 08 & $50 \%$ & 02 & $50 \%$ \\
\hline & $\mathbf{1 6}$ & $\mathbf{1 0 0 \%}$ & $\mathbf{0 4}$ & $\mathbf{1 0 0 \%}$ \\
\hline
\end{tabular}

Figure 6. Representation of Behavioural Process Participants in the Representation of NGE

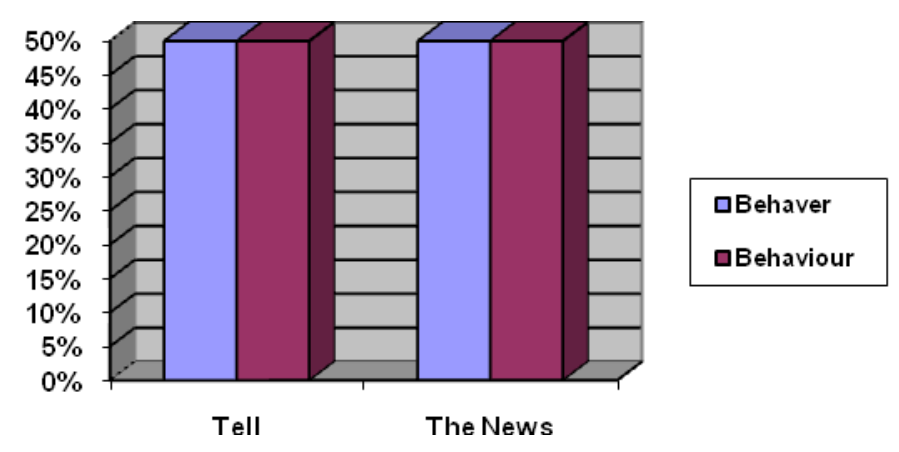

Let's consider the following extracts:

\begin{tabular}{|l|l|l|}
\hline Nigerians & look & to the year ahead with apprehension \\
\hline Behaver & Behavioural & Phenomenon \\
\hline S & F/P & A \\
\hline
\end{tabular}

Source: Tell magazine (January 6, 2003).

\begin{tabular}{|l|l|l|}
\hline Opposition parties and foreign observers & deplore & the polls as fraudulent \\
\hline Behaver & Behavioural & Phenomenon \\
\hline S & F/P & C \\
\hline
\end{tabular}

Source: The News magazine (May 5, 2003).

The examples below further explain the use of the behavioural process with emphasis on the clause types used by the different magazines in reporting their views.

- Extract 16: Nigerians look to the year ahead with apprehension (Tell, January 6, 2003).

In portraying the political terrain in Nigeria as dismal, the text producer uses generalisation in the subject position to describe Nigerians as anticipatory, 
fearful and anxious about the elections of that year. This is demonstrated with the use of the unquantifiable behavior.

- Extract 17: Opposition parties and foreign observers deplore the polls as fraudulent (The News, May 5, 2003).

In extract 17, the text producer's ideology that the election in Nigeria is fraudulent is expressed through the active roles played by the two non-human behavers, opposition parties (anti-PDP) and foreign observers (independent group) who deplored and condemned the election in Nigeria.

When attempts are made to hide the identities of social actors or background same, the grammatical strategy of agency obscuration is used. Passivation is a linguistic strategy which shows social actors as recipients of a given activity or event. Beyond this, it allows the text producer to be silent about the actors of specific events or to background such actors.

- Extract 18: Buhari deserted (The News, May 12, 2003).

The extract 18 above foregrounds the goal of the process. General Buhari is portrayed as the social actor who is deserted whereas the text producer obscures the actors that actually deserted him. The name Buhari is a household name in Nigerian politics. One sees here that the text producer is more concerned about what happens to the household name rather than who performed the action. This therefore provides a means of obscuring agency in reports.

- Extract 19: Reps offered N25 billion bribe (The News, November 28, 2005).

The construction above is a material process which backgrounds agency. Agency obscuration in this clause occurs in that instead of activating the giver of the N25 billion to the human recipient, Reps, it is excluded. The use of obscuration here is deliberate. The text producers believe that the masses are aware of the beneficiary of the third term if it eventually sails through. By implication, the one who dolls out the N25 billion becomes an open secret which the text producers do not necessarily have to highlight. Obviously, the issue of third term agenda has unveiled the obscured agent.

- Extract 20: Atiku begs Obasanjo (Tell, December 4, 2006).

Passivation takes place through participation. In this clause, Obasanjo is passivated to show that he is the recipient of the action carried out by Atiku. Chief Obasanjo is portrayed as a decider of Alhaji Atiku's faith at the polls, and dictates the tune of Nigerian politics. Hence, the need for Alhaji Atiku to give honour to whom it is due. 
Therefore, the magazines passivate social actors with goal in material process, phenomenon in mental process and carrier in an effective attributive process. Beyond the use of participation, social actors are also passivated through simple ellipses in non-finite clauses, infinitival clauses, adjectival premodification and possessivisation.

- Extract 21: ... wanted dead (The News, March 19, 2007).

In extract 21, President Yar'adua is the one wanted dead by his political opponents. With the use of simple ellipses in a non-finite clause, the report backgrounds and passivates the social actors who wanted him dead. The text producers also use infinitival clauses to passivate social actors as observed in the extract below.

- Extract 22: The plot to extend the tenure of President Olusegun Obasanjo thickens just as opposition against it heightens (Tell, December 5, 2005).

While the clause, to extend the tenure, discloses the intention, the actors involved in the process are passivated. In the two extracts below, we also have the cases of adjectival pre-modification and possessivisation in presidential ambition and his strategies respectively.

- Extract 23: Presidential ambition of former head of state, General Ibrahim Babangida (Tell, August 8, 2006).

- Extract 24: President Olusegun Obasanjo perfects his strategies to sit tight (The News, January 2, 2006).

The various ways through which both Tell and The News magazines have represented the major stakeholders in the 2003 and 2007 are linguistically ideological. Strategies such as linguistic processes with which specific events are reported: material, mental, verbal, relational, behavioural and existential are used in activating or passivating social actors. The activation and passivation of social actors are considered important, as "there need not be congruence between the roles that social actors actually play in social practices and the grammatical roles they are given in texts" (van Leeuwen, 1996, p. 43). Social actors are given active roles when they are represented as dynamic forces in a given activity, whereas when they are given passive roles to play, they are described as undergoing a given activity.

\section{Conclusion}

The analysis above has shown that the selected news magazines, representing the media practitioners, employ different strategies in allocating roles to the participants presented in various reports. The allocation of roles in the representation of social actors is a very important and useful tool in getting 
the ideology of news or text producers. In our data, while some of the social actors are represented as "agent" (actor), some are represented as "patient" (goal) in relation to a given action, and depending on the intention of the news producers. Activation is adopted by both magazines to identify the roles of specific actions and actors on the political landscape in Nigeria. Social actors are sometimes clearly distinguished in specific reports with the grammatical strategy of agency highlighting through activation. When text producers activate social actors, they are presented as the very active forces behind specific events, whereas when passivated, they are represented as recipient of the activity/event. Having passivated the social actors, some of them are subjected by being treated as objects, while others are beneficialised by being portrayed as the third party in a discourse which benefits from the action. The magazines passivate social actors with goal in material process, phenomenon in mental process and carrier in an effective attributive process. Beyond the use of participation, social actors are also passivated through simple ellipses in non-finite clauses, infinitival clauses, adjectival premodification and possessivisation.

The ideological basis of the allocation of roles to the various social actors is connected to the belief that the news magazines are the agents of social mobilisation in the dissemination and the control of the views of news consumers. The magazines hold the view that they are responsible for the social orientation of the electorate. This has necessitated the need to share in the consumers' general ideological affinity before gradually introducing and selling the ideas of the producers. This conforms with Halliday's view that the ideational function of the clause is meaning "representation" (1985, p. 101), that is, the clause functions to represent our experience of the world as language users; and that the system allows the clause to be broken down into three general components: the process, the participant and the circumstance. It also confirms van Leeuwen's view that the allocation of roles to participants in a discourse is a function of what is carried out by the participants. It is where social actors are represented through the roles they play. This bothers on who is represented as agent (actor), who is patient (goal) with respect to a given action $\ldots$ and that "there need not be congruence between the roles that social actors actually play in social practices and the grammatical roles they are given in texts" (van Leeuwen, 1996, 43). Further studies can consider some other means of deploying ideology in news reports, especially in on electoral discourse.

\section{References}

Alo, M. A. (2008). The representation of people in the news in the Nigerian print media. In A. Odebunmi, R. Taiwo \& A. Adetunji (Eds.), Perspectives on media discourse. Germany: Lincom Europa Publishers.

Bloor, T., \& Bloor, M. (1995). The functional analysis of English: a Hallidayan approach. London: Arnold. 
Butt, D., Fahey, F., Spinks, S., Yallop, C. (1995). Using functional grammar: an explorer's guide. Sydney: National Centre for English Language Teaching and Research, Macquarie University.

Chiluwa, I. E. (2005). Discourse pragmatics of news headlines and leadstories in Tell. The news and Newswatch, 1996-2002 (Unpublished doctoral dissertation). Department of English, University of Ibadan, Nigeria.

Chiluwa, I. E. (2008). Discourse features of Nigerian news magazine reporting. In A. Odebunmi, R. Taiwo \& A. Adetunji (Eds.), Perspectives on media discourse. Germany: Lincom Europa Publishers.

Eggins, S. (2004). An introduction to systemic functional linguistics (2nd ed.). New York: Continuum.

Fairclough, N. (1989). Language and Power. London: Longman.

Fairclough, N. (1992). Discourse and social change. Cambridge: Polity Press.

Halliday, M. A. K. (1985). An introduction to functional grammar. London: Arnold.

Halliday, M. A. K. (1994). An introduction to functional grammar (2nd ed.). London: Edward Arnold.

Halliday, M. A. K. (2004). An introduction to functional grammar. London: Arnold Publishers.

Henry, F., \& Tator, C. (2002). Discourses of domination: racial bias in the Canadian English language press. Toronto: University of Toronto Press.

Martin, J. R. (2001). Language, register and genre. In A. Burns \& C. Coffin (Eds.), Analysing English in a global context: a reader (149-166). London \& New York: Routledge.

Martin, J. R., Matthiessen, C. M., \& Painter, C. (1997). Working with functional grammar. London: Arnold.

Massi, M. P. (2008). Constructing identity and alterity in TV. In A. Odebunmi, R. Taiwo \& A. Adetunji (Eds.), Perspectives on media discourse. Germany: Lincom Europa Publishers.

Nunn, F. (2008). Values and truth in the international news: a case study. In A. Odebunmi, R. Taiwo \& A. Adetunji (Eds.), Perspectives on media discourse. Germany: Lincom Europa Publishers.

Odebunmi, A. (2008). Explicatures and implicatures in news magazine editorials: the case of the Nigerian TELL. In A. Odebunmi, R. Taiwo \& A. Adetunji (Eds.), Perspectives on media discourse. Germany: Lincom Europa Publishers.

Osisanwo, A. (2011). Language and ideology in news magazines' representation of Nigeria's 2003 and 2007 general elections (Unpublished doctoral dissertation). Department of English, University of Ibadan, Nigeria.

Osisanwo A. (2012) Conversationalization of discourse in Tell and The News' representation of Nigerian General Elections (NGE). Working Papers: Journal of English Studies, 5(1), 166-185.

Osisanwo, A. (2013). Discourse Representation in News Stories on Obasanjo's Thirdterm plot in TELL and THE NEWS. Ibadan Journal of Humanistic Studies, 23(1), $115-141$.

Oyeleye, L., \& Osisanwo, A. (2013a). Expression of Ideologies in the media Representation of the 2003 and 2007 General Elections in Nigeria. Discourse and Society, 24(6).

Oyeleye, L., \& Osisanwo, A. (2013b). Lexicalisation in media Representation of the 2003 and 2007 General Elections in Nigeria. World Journal of English Language, $3(2)$.

Pan, X. (2002). Consensus behind disputes: a critical discourse analysis of the right of abode issue in postcolonial Hong Kong. Media, Culture and Society, 24, 49-68. 
Scollon, R. (1998). Mediated discourse as social interaction: a study of news discourse. London and New York: Longman.

Simpson, P. (1993). Language, ideology and point of view. London: Routledge.

Taiwo, R. (2004). Speech as headline in Nigerian newspapers. In S. Awonusi \& E. A. Babalola (Eds.), The domestication of English in Nigeria (323-335). Lagos: University of Lagos Press.

Taiwo, R. (2008). Language, ideology and power relations in Nigerian newspaper headlines. Nebula: A Journal of Multidisciplinary Scholarship. Retrieved from http://www.nobleworld.biz.

Tell. 2003-2007. Lagos: TELL Communications Limited.

Teo, P. (2000). Racism in the news: a critical discourse analysis of news reporting in two Australia newspapers. Discourse and Society, 11: 7-49.

The News Magazine 2003-2007. Lagos: The News Communications Limited.

Thompson, G. (1996). Introducing functional grammar. London: Arnold.

van Dijk, T. A. (1998) Ideology: A multidisciplinary approach. Newbury Park, CA: SAGE.

van Leeuwen, T. (1996). The representation of social actors. In C. R. CaldasCoulthard \& M. Coulthard (Eds.). Texts and practices: readings in critical discourse analysis (32-70). London \& New York: Routledge. 